\title{
Physioiogical Properties of Clostridia Isolated from the Sediment in the Edo River Mouth
}

\author{
Haruo Sugita, Hideo TANaAmI, and Yoshiaki Deguch ${ }^{*}$ \\ (Accepted January 19, 1983)
}

\begin{abstract}
One hundred and thirty eight strains of obligately anaerobic heterotrophs, genus Clostridium, were isolated from the sediment in the Edo River mouth using 5 different agar media, and examined for 19 physiological characteristics. Almost all strains produced proteolytic and saccharolytic enzymes and lecithinase. Few or none of the isolates produced cellulase, chitinase and lipase. Many organisms could grow in 0 to $2 \% \mathrm{NaCl}$ and at $20^{\circ} \mathrm{C}$ to $37^{\circ} \mathrm{C}$. Obligate halophiles were not isolated from the estuarine sediment. It is shown from the characteristics of casein hydrolysis, fermentation of lactose and sucrose and growth at $10^{\circ} \mathrm{C}$ that the clostridial composition varied with the temperature and/or with the medium to be isolated.

The isolates were classified into 13 groups based on 7 characteristics which are important in the taxonomy of genus Clostridium. Groups 3,5 and 7 showed relatively high proportions of the isolates. Especially group 5 which seems to be $C$. perfringens, distributed widely in the sediment of the inner part of Tokyo Bay.
\end{abstract}

Although considerable information has been accumulated on the aerobic and facultatively anaerobic bacteria in ocean waters and sediments, there has been few investigations of obligate anaerobes with the exception of pathogenic bacteria. ${ }^{1-4}$ ) Sugrta et al. ${ }^{5}$ ) investigated on the bacterial flora of the sediment in the Edo River mouth which is located in the inner part of Tokyo Bay from May 1980 to March 1981, and found that obligately anaerobic spore-forming heterotrophs, genus Clostridium, predominated with population density of $10^{8}$ to $10^{4}$ per gram of sediment. Clostridia are known to be present in marine and freshwater sediments. ${ }^{8,7}$ ) However, the ecology of these bacteria in aquatic environments has yet not been clarified.

As the distribution of organisms is restricted by environmental factors, the investigation of physiological properties of isolates is of important to assume the ecology of these bacteria. In the present paper we shall describe the characteristics of clostridia isolated from the sediment in the Edo River mouth.

\section{Materials and Methods}

\section{Isolation Procedure}

Sediment samples were collected at stations 1,2 and 3 in the Edo River mouth from December
1980 to September 1981 using SexI's bottom sampler (Rigosha) as described previously. ${ }^{\text {b) }}$ Water samples were collected using KITAHARA's sampler (Rigosha). The sediment was diluted quantitatively with seawater diluent ${ }^{8)}$ and inoculated onto PYBG agar, ${ }^{\text {8) }}$ 1/20 PYBG agar, ${ }^{8)}$ N-PYBG agar, ${ }^{8)}$ GAM agar (Nissui) and FM-CW agar (Eiken). Inoculated PYBG, 1/20 PYBG, N-PYBG and GAM agar plates were incubated at $20^{\circ} \mathrm{C}$ for 5 days and FM-CW agar plate, at $37^{\circ} \mathrm{C}$ for 2 to 3 days, both under anaerobic condition. Anaerobiosis was established by evacuating the atmosphere of an anaerobic jar containing steel wool which was activated by an acidic cupric sulfate solution and replacing the atmosphere with $\mathrm{CO}_{2}$ gas. ${ }^{8)}$

After incubation, colonies were divided into some types according to colonial morphology. Each representative colony type was plated on PYBG or $1 / 20$ PYBG agar, and purified by a second streaking onto the same medium.

The purified bacteria were examined on the basis of Gram reaction, cellular morphology, aerobic growth and spore formation. The isolates identified as genus Clostridium were preserved in cooked meat medium (BBL) and/or chopped meat medium. ${ }^{10)}$ Both media were prepared with $1 \%$ $\mathrm{NaCl}$ solution instead of distilled water.

\section{Physiological Tests}

* Department of Fisheries, College of Agriculture and Veterinary Medicine, Nihon University, Setagaya, Tokyo 154, Japan（杉田治男・苫網唀男・出口吉昭：日本大学费獣医学部水産学科). 

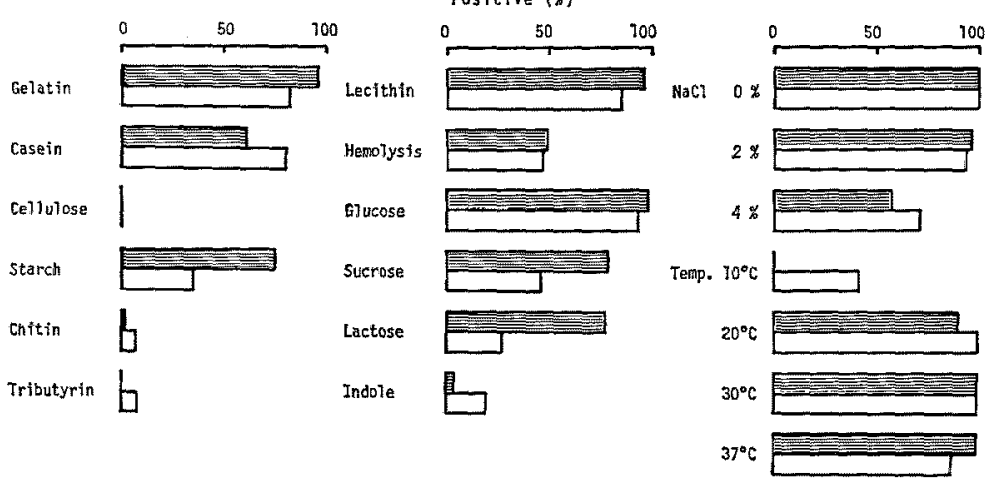

Fig. 1. Physiological properties of clostridia isolated at $37^{\circ} \mathrm{C}$ ( and $20^{\circ} \mathrm{C}(\square)$ from the sediment of the Edo River mouth.

For preparation of inocula, modified peptoneyeast extract-Fildes solution (modified PYF) broth $^{11)}$ with $0.1 \%$ glucose was used. The composition of modified PYF broth was as follows: Trypticase peptone (BBL), $5 \mathrm{~g}$; Proteose peptone No. 3 (Difco), $5 \mathrm{~g}$; Bacto-yeast extract (Difco), $10 \mathrm{~g}$; Fildes peptic digest of blood (Fildes solution), $40 \mathrm{~m} l$; mixture of $0.03 \% \mathrm{CaCl}_{2} \cdot 2 \mathrm{H}_{2} \mathrm{O}, 0.04 \%$ $\mathrm{MgSO}_{4} \cdot 7 \mathrm{H}_{2} \mathrm{O}, 0.1 \% \mathrm{~K}_{2} \mathrm{HPO}_{4}, 0.1 \% \mathrm{KH}_{2} \mathrm{PO}_{4}$ and $1 \%$ of $\mathrm{NaHCO}_{s}$ (salts solution), $40 \mathrm{ml} ; \mathrm{NaCl}$, $10 \mathrm{~g}$; L-cysteine $\cdot \mathrm{HCl} \cdot \mathrm{H}_{2} \mathrm{O}, 0.5 \mathrm{~g}$; distilled water, $920 \mathrm{ml} ; \mathrm{pH}$ 7.6. The medium was autoclaved at $115^{\circ} \mathrm{C}$ for $20 \mathrm{~min}$ and, after cooling, was aseptically supplemented with $0.05 \mathrm{ml}$ of ascorbic acidcysteine solution per $3 \mathrm{~m} l$ immediately before use.

The abilities to hydrolyze casein, cellulose, starch, chitin, tributyrin and lecithin were examined on modified EG-F agar ${ }^{11)}$ supplemented with $2 \%$ casein (NBC), 0.5\% Avicel (Asahi Kasei), 0.5\% starch, $5 \%$ precipitated chitin, $2 \%$ tributyrin or $10 \%$ egg yolk. The composition of modified EG-F agar was as follows: Lab-lemco powder (Oxoid), $2.4 \mathrm{~g}$; Proteose peptone No. 3 (Difco), $10 \mathrm{~g}$; Bacto-yeast extract (Difco), $5 \mathrm{~g} ; \mathrm{Na}_{2} \mathrm{HPO}_{4}$, $4 \mathrm{~g} ; \mathrm{NaCl}, 10 \mathrm{~g}$; Fildes solution, $40 \mathrm{ml}$, L-cysteine. $\mathrm{HCl} \cdot \mathrm{H}_{2} \mathrm{O}, 0.5 \mathrm{~g}$; Agar No. 1 (Oxoid), $10 \mathrm{~g}$; distilled water, $960 \mathrm{ml} ; \mathrm{pH} 7.6$. The ability to hemolyze horse blood was examined on EG-F agar. The isolates were inoculated on test media, and incubated at $30^{\circ} \mathrm{C}$ in an anaerobic, steel wool jar with an atmosphere of $90 \% \mathrm{~N}_{2}-10 \% \mathrm{CO}_{2}$ for 5 to 10 days. Hydrolysis of cellulose, chitin and tributyrin was recognized as a clear zone around colonies. To detect hydrolysis of casein, test plate was flooded with a $15 \%$ solution of mercuric chloride in $\mathrm{HCl}$. Starch hydrolysis was determined by a clearing of the medium around the colonies by flooding the plate with Lugol iodine solution.

Acid production from carbohydrates was determined in modified PYF broth containing $0.5 \%$ (w/v) of the carbohydrates to be tested. For the determination of sugar fermentation, $\mathrm{pH}$ value was measured diectly in culture tube by a long combination electrode as recommended by HoLdEMAN et al. ${ }^{10)}$

Indole production was determined in indolenitrate medium (BBL) supplemented with Fildes solution by adding Kovacs reagent. ${ }^{10}$ )

The isolates were also tested for their abilities to grow in 0,2 and $4 \% \mathrm{NaCl}$ and at $10,20,30$ and $37^{\circ} \mathrm{C}$ using EG-F agar as basal medium. LCysteine, $\mathrm{NaCl}$ and Fildes solution were omitted from EG-F agar to examine the growth in $0 \%$ $\mathrm{NaCl}$.

\section{Results and Discussion}

The Edo River mouth with the water depths of 1.5 to $15.5 \mathrm{~m}$, is a polluted area, and the anoxic water mass, called "Aoshio", was observed at the depth more than $10 \mathrm{~m}$ from June to September 1981. Some environmental factors in lower water from December 1980 to September 1981 had the following characteristics: Chlorinity, 5.00$14.89 \%$; water temperature, $9.2-27.7^{\circ} \mathrm{C}$, dissolved oxygen, $0.0-9.2 \mathrm{ppm}$; chemical oxygen demand (COD), 0.2-2.5 ppm.

Total viable counts and viable counts of clostridia in the sediment were $10^{8} \mathrm{~g}^{-1}$ and $10^{8}$ to $10^{4} \mathrm{~g}^{-1}$, respectively, as same population densities as reported previously. ${ }^{b 2}$ of 138 strains, 76 and 62 strains were isolated at $37^{\circ} \mathrm{C}$ (FM-CW agar) and 
Table 1. Grouping of clostridia isolated from the sediment in the EDo River mouth, Tokyo Bay

\begin{tabular}{|c|c|c|c|c|c|c|c|c|c|}
\hline \multirow{2}{*}{ Group } & \multirow{2}{*}{ Gelatin } & \multirow{2}{*}{ Lipase } & \multirow{2}{*}{ Lecithinase } & \multirow{2}{*}{ Indole } & \multirow{2}{*}{ Glucose } & \multirow{2}{*}{ Lactose } & \multirow{2}{*}{ Sucrose } & \multicolumn{2}{|c|}{ Isolates at } \\
\hline & & & & & & & & $20^{\circ} \mathrm{C}$ & $37^{\circ} \mathrm{C}$ \\
\hline 1 & + & + & + & - & + & - & + & $5^{*}$ & 0 \\
\hline 2 & + & - & + & + & + & + & + & 0 & 2 \\
\hline 3 & + & - & + & + & + & - & - & 12 & 1 \\
\hline 4 & + & - & + & + & - & - & - & 1 & 0 \\
\hline 5 & + & - & + & - & + & + & + & 10 & 55 \\
\hline 6 & + & - & + & - & + & - & + & 4 & 2 \\
\hline 7 & + & - & + & - & + & - & - & 17 & 12 \\
\hline 8 & + & - & + & - & + & + & - & 0 & 1 \\
\hline 9 & + & - & - & - & - & - & - & 2 & 1 \\
\hline 10 & - & - & + & - & + & + & + & 6 & 1 \\
\hline 11 & - & - & + & - & + & + & - & 1 & 0 \\
\hline 12 & - & - & + & - & + & - & - & 1 & 0 \\
\hline 13 & - & - & - & - & + & + & + & 3 & 1 \\
\hline Total & & & & & & & & 62 & 76 \\
\hline
\end{tabular}

- Number of isolates.

$20^{\circ} \mathrm{C}$ (other agars), respectively. Physiological properties of clostridia are shown in Fig. 1.

Almost all strains produced protease and liquefied gelatin and/or hydrolyzed casein. Few or none of isolates hydrolyzed cellulose, chitin and tributyrin. Thirty six to $76 \%$ of isolates hydrolyzed starch and 86 to $97 \%$ produced lecithinase. About a half showed $\beta$-hemolysis of horse blood. Almost all strains could utilized glucose, but fermentation of sucrose and lactose differed somewhat with the temperature at which the organism was isolated. Only a few strains produced indole. Many organisms could grow in 0 to $2 \%$ $\mathrm{NaCl}$, and obligately halophilic bacteria were not isolated. Almost all strains could grow at 20 to $37^{\circ} \mathrm{C}$, but 42 strains which could be isolated only at $20^{\circ} \mathrm{C}$ were able to grow at $10^{\circ} \mathrm{C}$. It is suggested from these results that clostridial composition varied with the temperature and/or with the medium to be isolated. As water temperature of lower layer decreases to less than $10^{\circ} \mathrm{C}$ in winter, it must be important to clarify whether these organisms are present in situ with vegetative or dormant form.

Of 19 characteristics tested, gelatin liquefaction, production of lipase, lecithinase and indole, and fermentation of glucose, lactose and sucrose are known to be very important in the taxonomy of genus Clostridium. Therefore, 138 strains isolated from the sediment were divided into 13 groups based on 7 characters as shown in Table 1. Group 5 and 7 occupied in relatively high proportion among the strains isolated at $37^{\circ} \mathrm{C}$, and in addition, group 3 also showed high percent among the organisms isolated at $20^{\circ} \mathrm{C}$. Although the proportion of group 5 was noticeable in the strains isolated at $37^{\circ} \mathrm{C}$, this may be due to the medium used to isolate, which is a selective and differential medium for Clostridium perfringens.

According to the VPI manual, ${ }^{b /}$ group 5 seem to be $C$. perfringens or $C$. sardiniensis. These bacteria, especially the former is known to occur in polluted areas. ${ }^{2,10,12)}$ MATCHes and LisToN ${ }^{13)}$ isolated 244 strains of clostridia from sediments in Puget Sound and reported that most of these organisms were mainly composed of $C$. perfringens $(37.3 \%), C$. bifermentans $(21.3 \%)$ and $C$. novyi $(17.2 \%)$. Sugrta et al. $\left.{ }^{14}\right)$ have isolated 42 strains of the clostridia from benthic animals and sediments in the Sanmaizu Bar, Tokyo Bay, and $76 \%$ of organisms seem to be group 5. Thus, group 5 are predominantly present in the polluted area such as the inner part of Tokyo Bay. As reported by WooD and TRUST, ${ }^{15)}$ and MATCHES et al., ${ }^{2}$ the bacteria belonging to group 5 may have originated from sewage, freshwater sediments, soil and/or bird feces.

Although $C$. oceanicum and $C$. stricklandii are known to be originated from marine sediments ${ }^{1 \theta, 17}$ ) their salt requirement which should be an important characteristics in marine bacteria, ${ }^{18}$ ) has yet not been clarified. DAILY et al. ${ }^{\text {) }}$ studied obligate anaerobes in estuaries, and reported that the isolation of anaerobes was limitted to the area with a relatively low salinity. Our results also show that halophilic clostridia were failed to be isolated. There are still problem whether a truly marine type of clostridia is present. Further study concerning 
this problem should be performed.

\section{References}

1) B. O. Ward, B. J. Carrol, E. S. Garret, and G. B. ReEsE: Appl. Microbiol., 15, 629-636 (1967).

2) J. R. Matches, J. Liston, and D. Curran: Appl. Microbiol., 28, 655-660 (1974).

3) S. OKa: Bull. Japan. Soc. Sci. Fish., 43, 567575 (1977).

4) H. H. Huss: Appl. Environ. Microbiol., 39, 764-769 (1980).

5) H. Sugrta, H. TanaAmi, T. Kobashi, and $Y$. DEGUCHI: Jap. J. Limnol., 43, 27-34 (1982).

6) L. Ds. SMith and G. Hobbs: in "Bergey's Manual of Determinative Bacteriology, 8th edition" (ed. by R. E. Buchanan and N E. Gibbons), The Williams \& Wilkins, Baltimore, 1974, pp. 551572.

7) O. P. Daily, S. W. Joseph, J. D. Gillmore, R. R. ColWell, and R. J. SEIDLER: Appl. Environ. Microbiol., 41, 1074-1077 (1981).

8) H. Sugita, H. TanaAm, T. Kobashi, and Y. DEGUCHI: Bull. Japan. Soc. Sci. Fish., 47, 655661 (1981).
9) A. AzUMA, K. Ogimoto, and K. Suto: Japan. J. Bacteriol., 17, 802-806 (1962).

10) L. V. Holdeman, E. P. Cato, and W. E. C. Moore: Anaerobe Laboratory Manual, 4th edition. Anaerobe Laboratory, Virginia Polytechnic Institute and State University, Blacksburg, 1977, pp. 1-156.

11) C. Kaneuchi, K. Watanabe, A. Terada, Y. Benno, and T. Mitsuoka: Int. J. System. Bacteriol, 26, 195-204 (1976).

12) L. Ds. SmTrH； Can.J. Microbiol., 14, 1301-1304 (1968).

13) J. R. MAtches and J. Liston: in "Microbial Ecology" (ed. by L. H. Stevenson and R.R. Colweflu), University of South Carolina Press, Columbia, 1973, pp. 345-362.

14) H. Sugtita, H. TaNAami, and Y. DeguchI: Bull. Japan. Soc, Sci. Fish., 48, 1005 (1982).

15) A. J. Woon and T. J. Trust: Can.J. Microbiol., 18, 1577-1583 (1972).

16) T. C. Stadtman and L.S. MCClung: J. Bacteriol., 73, 218-219 (1957).

17) L. Ds. SMITH: J. Bacteriol., 103, 811-813 (1970).

18) Y. MaruYama: in "Kaiyo Biseibutsu (Marine Microbiology)" (ed. by N. TAGA), University of Tokyo Press, Tokyo, 1974, pp. 7-16. 